\title{
Origin of Caves in Quaternary Fluvial Deposits at the Left Side of Mosul City-Iraq
}

\author{
Bassam M. Al-Dewachi \\ Remote Sensing Center \\ Mosul University
}

(Received 7/8/2004 , Accepted 5/1/2005)

\begin{abstract}
Generally many major and minor karstic phenomenas have been identified and studied by many researchers at Mosul region, with emphasis mainly on sinkholes that developed at highly water-soluble rocks such as limestone, marly limestone and gypsum that dominated the local geological formations here. The caves in the present study which constitute one of the important karstic phenomena in the area were developed and formed in conglomeritic rocks of fluvial deposits of Quaternary age .This type of occurrence is internationally considered to be very rare. The reasons behind that is firstly the presence of certain type of conglomeritic rocks which consist of calcareous matrix cementing various types of conglomerate fragments. This is the main factor that should be present prior to any development and formation of the caves. The second factor is the abundance of high rate of rainfall leading to the enrichment of underground waters. It is suggested, in the present study that wet Pliestocene climate is the most probable time for the initiation and formation of the caves in the fluvial deposits. This has also been suggested for other karstic phenomenas formed in other geological formations of Mosul city and its neighborhood, north of Iraq.
\end{abstract}

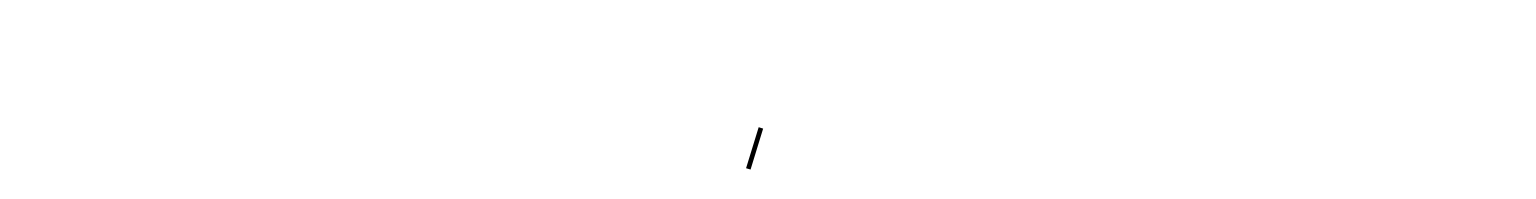

\section{الملغص}

الظواهر الكارستية الرئيسية والثانوية علمة قد م التعرف عليها وكذلك تمت درلستها من قبل العديد من البلحثن في مطقة الموصل مع التركيز خصوصاً علىظاهرة البالوعلت التي قطورت وقم تشت كيلها في الصخور ذات قابلية الذوبان العالية مل الصخور الكلد ية، والمارلي ـة والجبد ية والمتولج ــة ف ي في التكوينت الجيولوجية المختلفة في مدينة الموصل وضولية الفولية المالية الحيها.

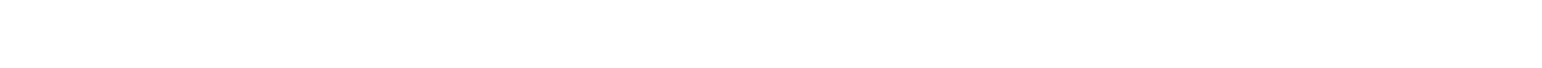

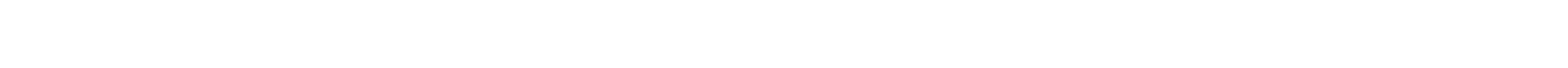
وحق على المستوى العالهي وفي هكذا نوع من الصخور. 


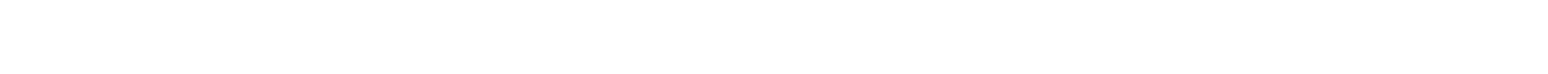

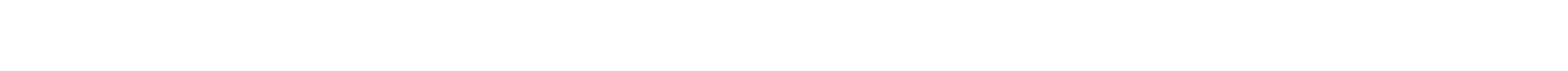

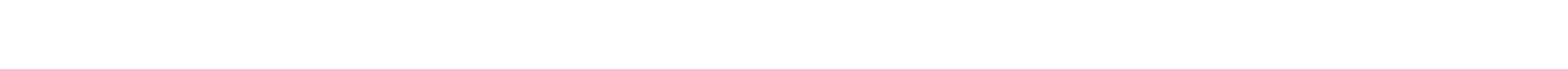

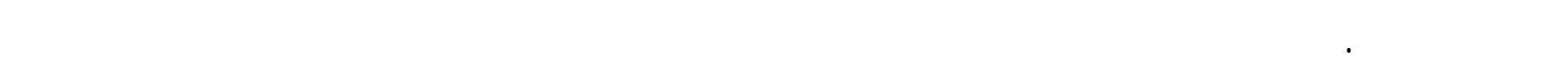

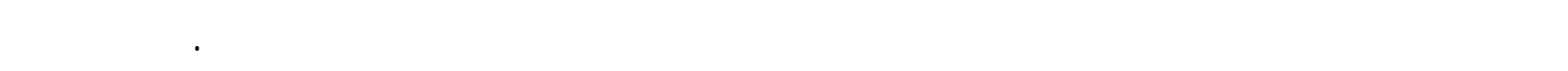

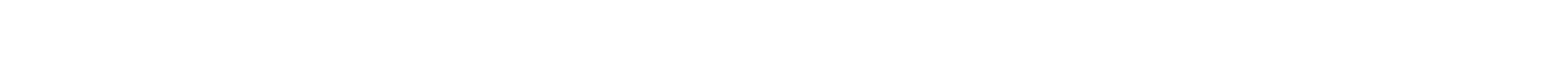

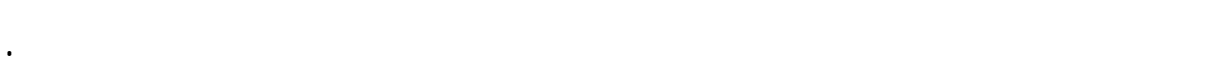

\section{INTRODUCTION}

Monroe and Wicander (1992) classified the caves as one form of the karstic phenomena or landform also they defined a cave as "A naturally formed subsurface opening that is generally connected to the surface and is large enough for a person to enter.” Karstic phenomena have been identified and studied by many authors at northern Iraq, in Mosul region including Mosul city, with emphasis mainly on the sinkholes, (AlSabti et al., 1989, Jassim et al., 1997 and Al-Dewachi., 2001). On the other hand, the study of caves is of less importance and sometimes is totally ignored, despite the presence of this karstic phenomena in northern Iraq and Mosul city and region where they have been developed in the highly soluble sedimentary rocks of different geological formations such as Pilaspi limestone Formation (Upper Eocene) (Plate 1), at the south western limb of Jabal Maklub. In the Sinjar limestone Formation, (Paleocene to lower Eocene) (Plate 2), at the northern limb of Jabal Sinjar along the road between Sinjar and Karsi village.In the Serikagni Marly limestone Formation (Lower Miocene) at the southern limb of Jabal Sinjar ,between Sinjar and Karsi village (Plate 3). And in the gypsum of Al-Fat'ha Formation (Middle Miocene) at Abu-Fshika village about (40) Kilometer south of Mosul at the highway between Mosul and Baghdad (Plate 4). The present study will emphasis on the caves inside Mosul city which were formed in the conglomeritic rocks (Quaternary) (Plates 5 and 6), and believed to have identical genesis of karstic phenomena found in Italy (Belloni et al., 1972).

It is also worthwhile to mention that these caves have not been delineated and identified through the visual remote sensing technique (Visual Photo-interpretation).The reasons for that are probably due to the aerial photographs available which are of scale $(1: 50,000)$, and which is too small to identify or delineate such features.

The purpose of the present study is to discuss causes and conditions behind the formations of many caves in conglomeritic unit which has been assigned by (GEOSURV) as being of Quaternary deposits and is situated on the left bank and in the northern part of Mosul city-Iraq.

\section{GEOLOGICAL AND GEOGRAPHICAL SETTING OF THE CAVES}

Geological map of Mosul quadrangle (1996) and field observation and study prevail an area which extends about a couple of square kilometers located now within the eastern side of Mosul city and part of Mosul University campus occupied it. This area was mapped as a separate geological unit and assigned as fluvial deposits of Quaternary age. 


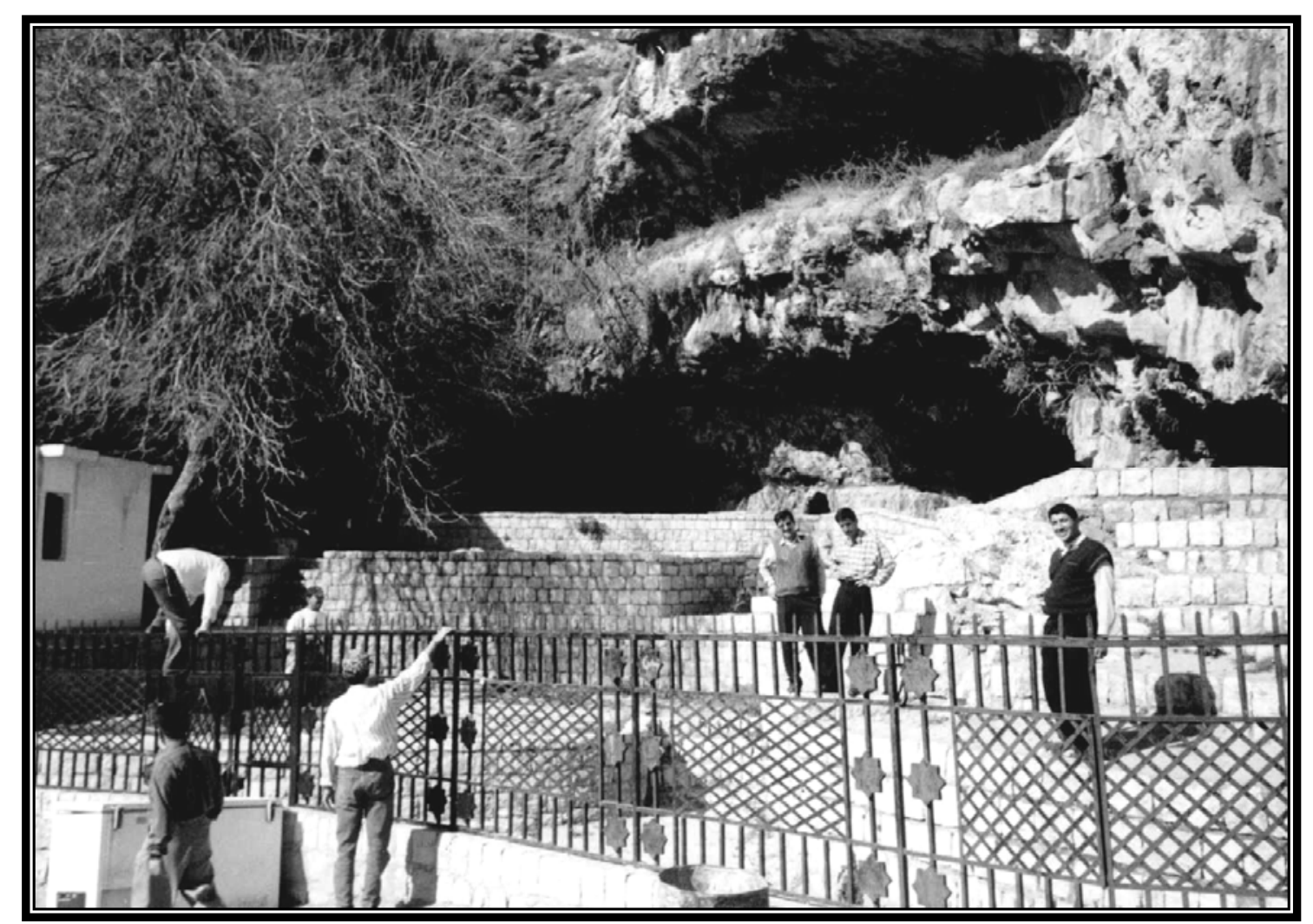

Plate 1: A cave in Pila Spi Limestone Formation (Upper Miocene), Southwestern limb of Jabal Maqlub, Nineva District.

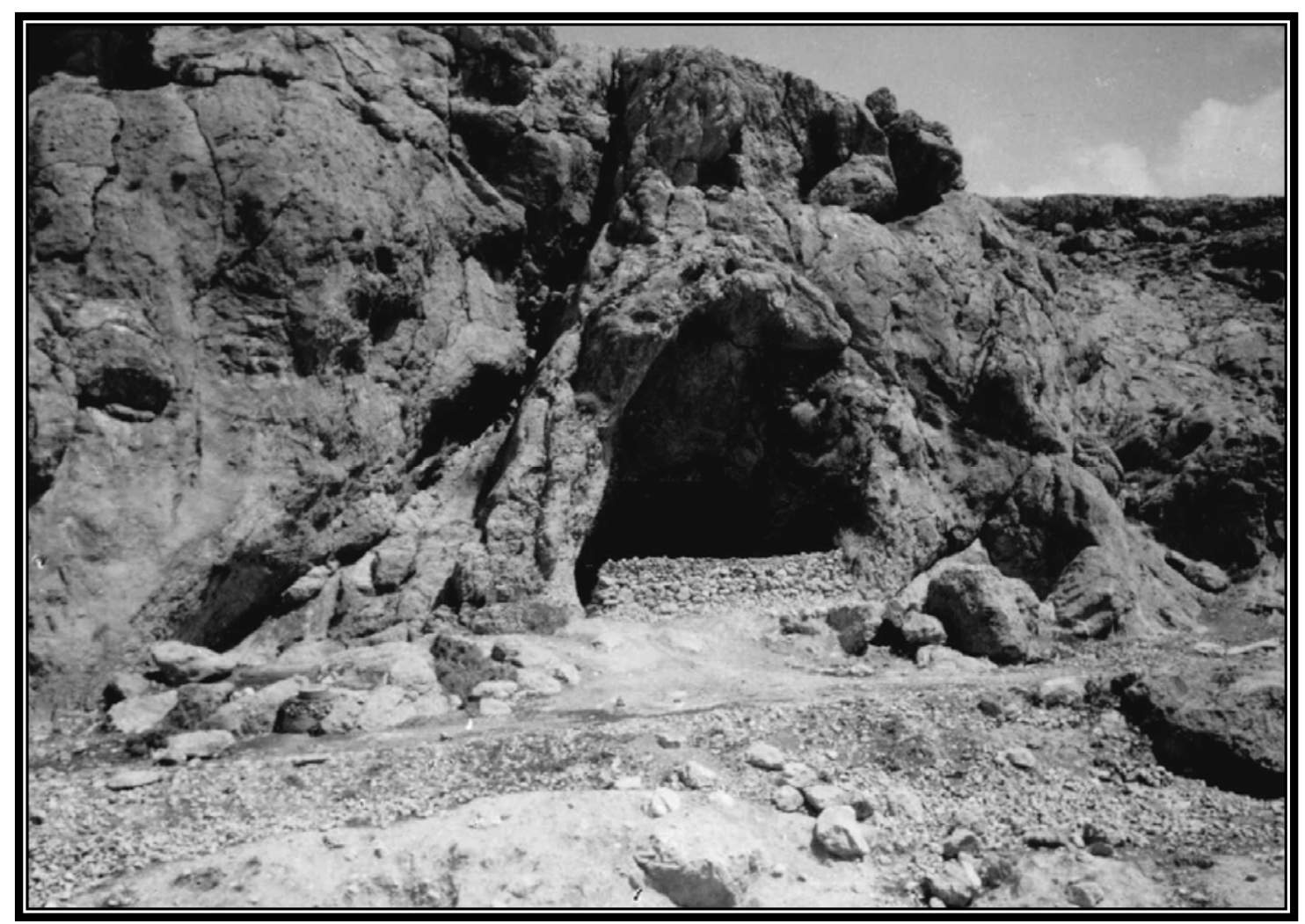

Plate 2: A cave in the Sinjar Limestone Formation (Paleocene-Lower Eocene) at the northern limb of Jabal Sinjar, Ninevah District. 


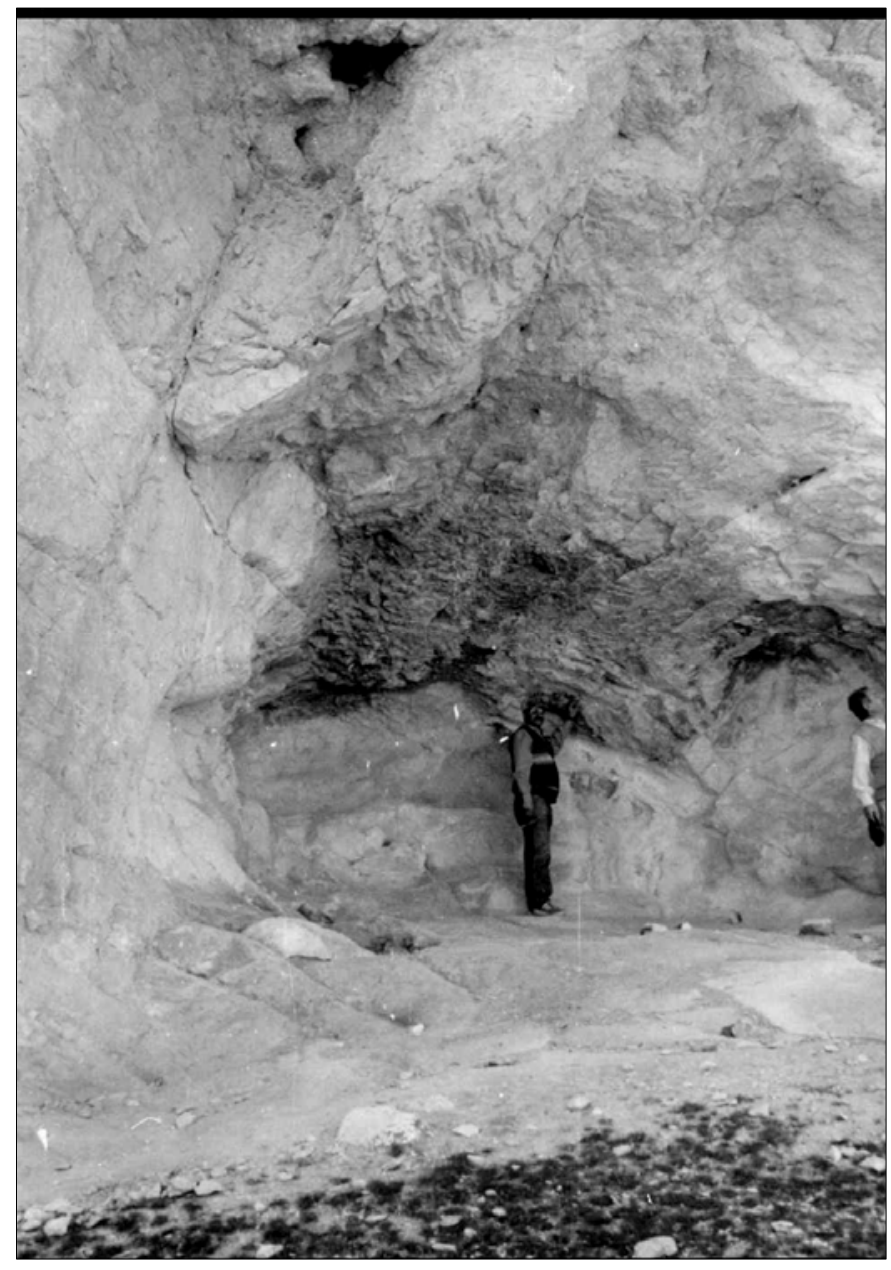

Plate 3: A cave in the Serikagni Marly Limestone Formation (Lower Miocene) at the Southern limb of Jabal Sinjar, Ninevah District

Plate 4: A cave in the Gypsum of Al-Fat'ha Formation (Middle Miocene) at Abu-Fshika village, south of Mosul, Ninevah District.

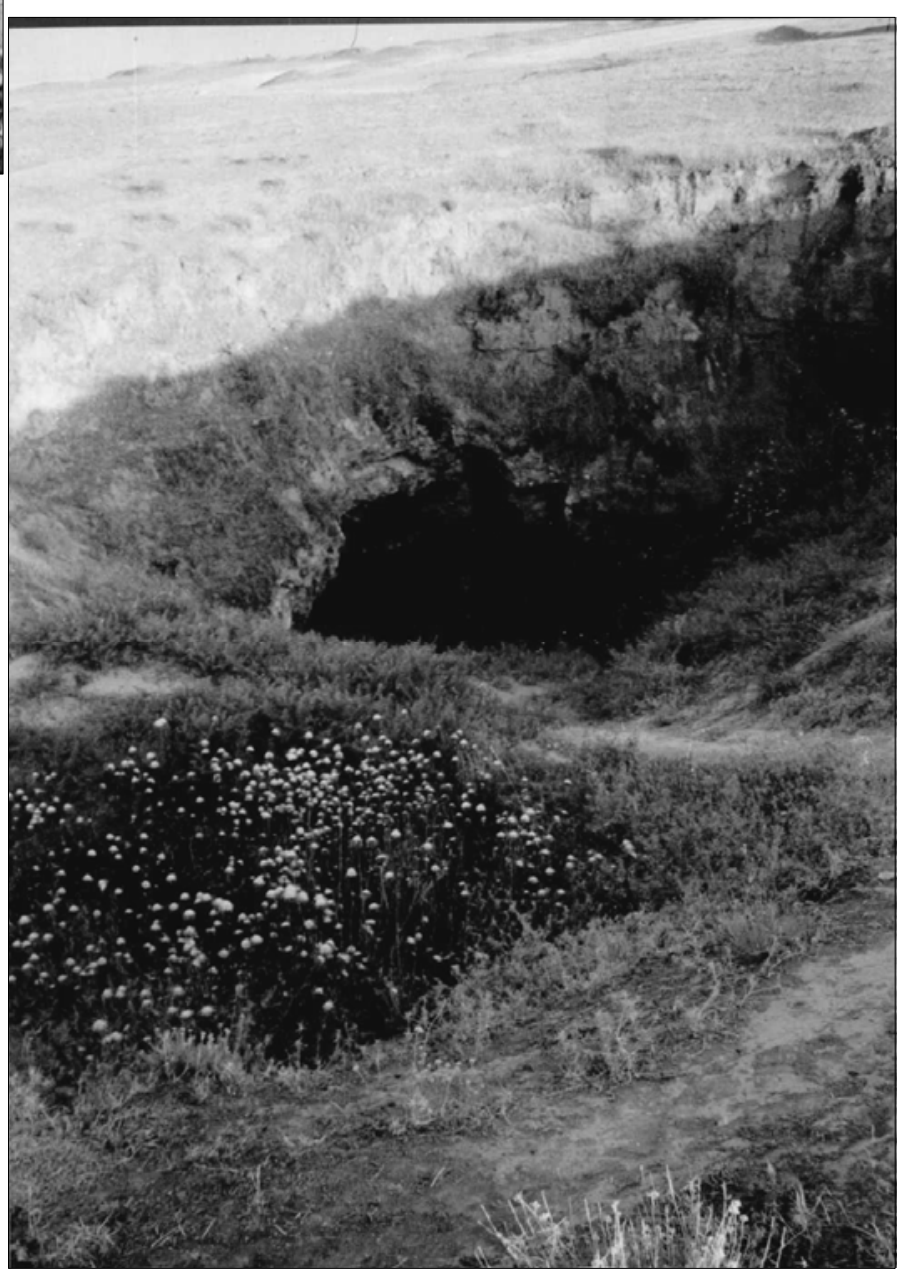




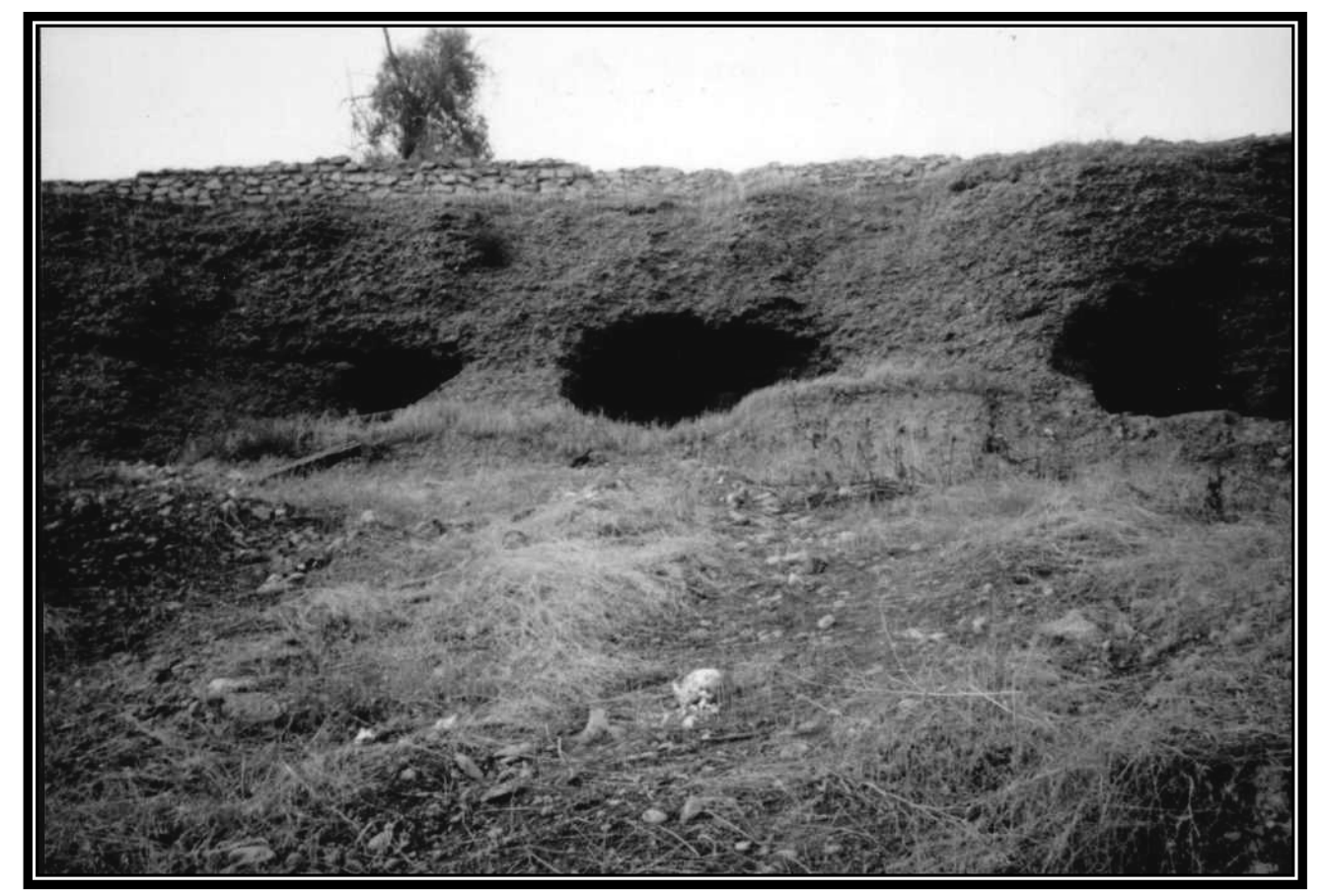

Plate (5)

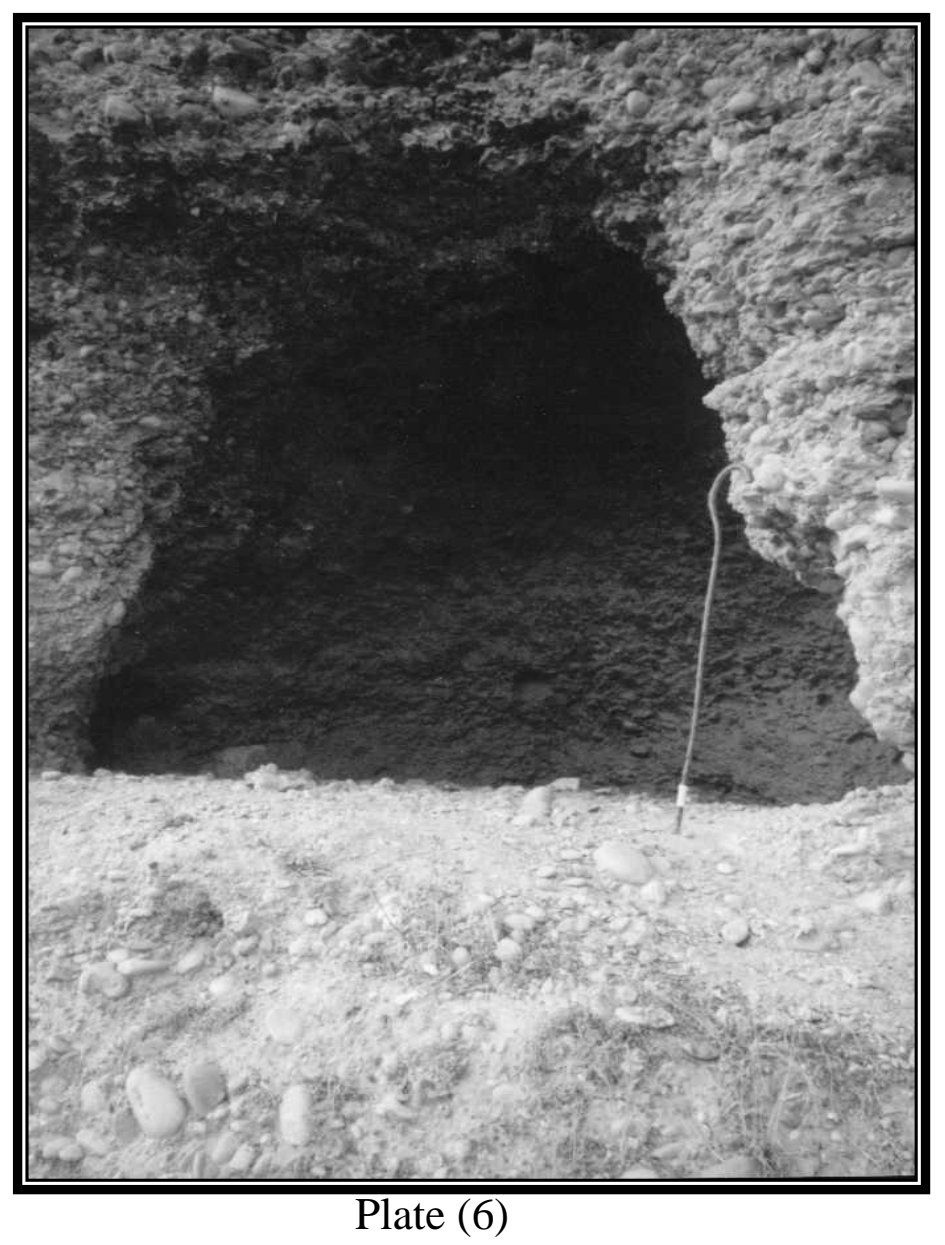

Plates 5 and 6: Caves in the conglomeritic rocks (Quaternary), Mosul City, near Mosul University, Ninevah District. 
It unconformably overlies the Fat'ha Formation (Middle Miocene) and the most lower part of Injana Formation (Upper Miocene). The contact between theses two formations sometime show angular unconformity. The area in general is described as Hummoky landform which dissected by small valleys. The maximum thickness of the outcrop is ranging between (2-15) meters, while some subsurface drilling showing sometime (30) meters thickness.

Geographically this area is bounded by the present river bed of Tigris river (Fig.1) which is located at the east of it, also sometime the present Tigris rive is far about (3-5) Kilometers. The geological relationship between the present Tigris River and this area and whether it is terraces deposits of this river or not is unknown and need further investigation which is beyond the scope of the present study.

Details of lithostratgraphic study of this unit shows that it consist mainly of massive, indurated conglomerate, especially around and inside the cave positions (Plate 7), but in other localities the conglomerate is well stratified, imbricated and showing fining upward sequences (Plate 8) and some sandstone lenses (Plate 9). The fragments of the conglomerates are of different sizes ranging between pebbles and cobbles according to Uden-Went Worth classification (Blatt et al, 1972), the shape of the pebbles is rounded to subrounded .The fragments of this conglomerate are of different origin(sedimentary, metamorphic and igneous). All these properties of the conglomerate point out that it is an orthoconglomerate i.e. ordinary or normal conglomerate which have been collected by ordinary water current according to Pettijohn, (1975).

The matrix that engulfed or the fragments floated in it are calcareous or fine to very fine sandstone and that especially around and inside the caves, in other places the matrix is mainly clay.

The origin of the calcarous matrix, whether it is primary (detrital) or secondary (calcrete) is of controversy and requires further investigations. There is no doubt that calcareous matrix are the main reason behind the initiation, development and formation of the caves in the conglomeritic rocks which are quite similar to those described by (Belloni et al., 1972) in Pantian formation of Italy.

\section{GENESIS AND ORIGIN OF THE CAVES}

According to Selby (1985) and Thrailkill (1968) two main factors behind the formation of the caves as well as other karstic forms of either minor or major size and these are: (a) The lithology of the rocks which has been discussed in details above and (b) the climate which is usually should be wet with enough rainfall feeding underground reservoirs for excavation and formation of the caves.

All rainfall is naturally somewhat acidic because some $\left(\mathrm{CO}_{2}\right)$ in the air reacts with water vapor to form carbonic acid $\left(\mathrm{H}_{2} \mathrm{CO}_{3}\right)$ (Montgomery, 1997). The rain water then penetrates the surface of the earth and percolates through the zone of aeration slowly forming ground water that dissolves the carbonate rock (the calcareous matrix in our case) and enlarge it. Upon reaching the water table, the ground water migrates toward surface streams. As groundwater moves through the zone of saturation, it continues to dissolve the calcareous matrix and gradually form a system of horizontal passage ways through which the dissolved rocks carried to the streams. As the surface stream erodes deeper valleys, the water table drops in response to the lower elevation of the stream. The water that flowed through the system of horizontal passage ways now percolates down to 


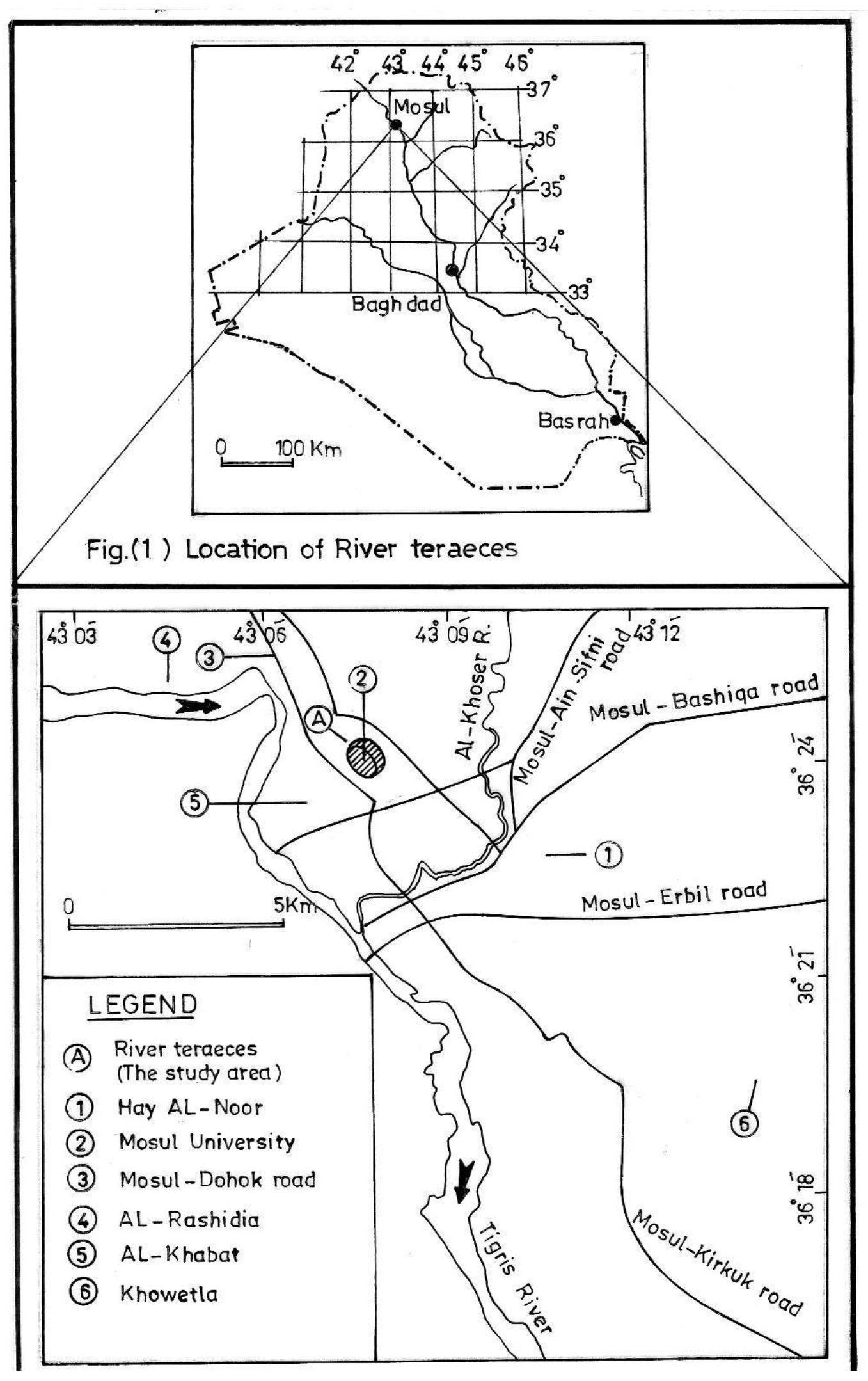

Fig.1: Location of Quaternary fluvial deposits. 


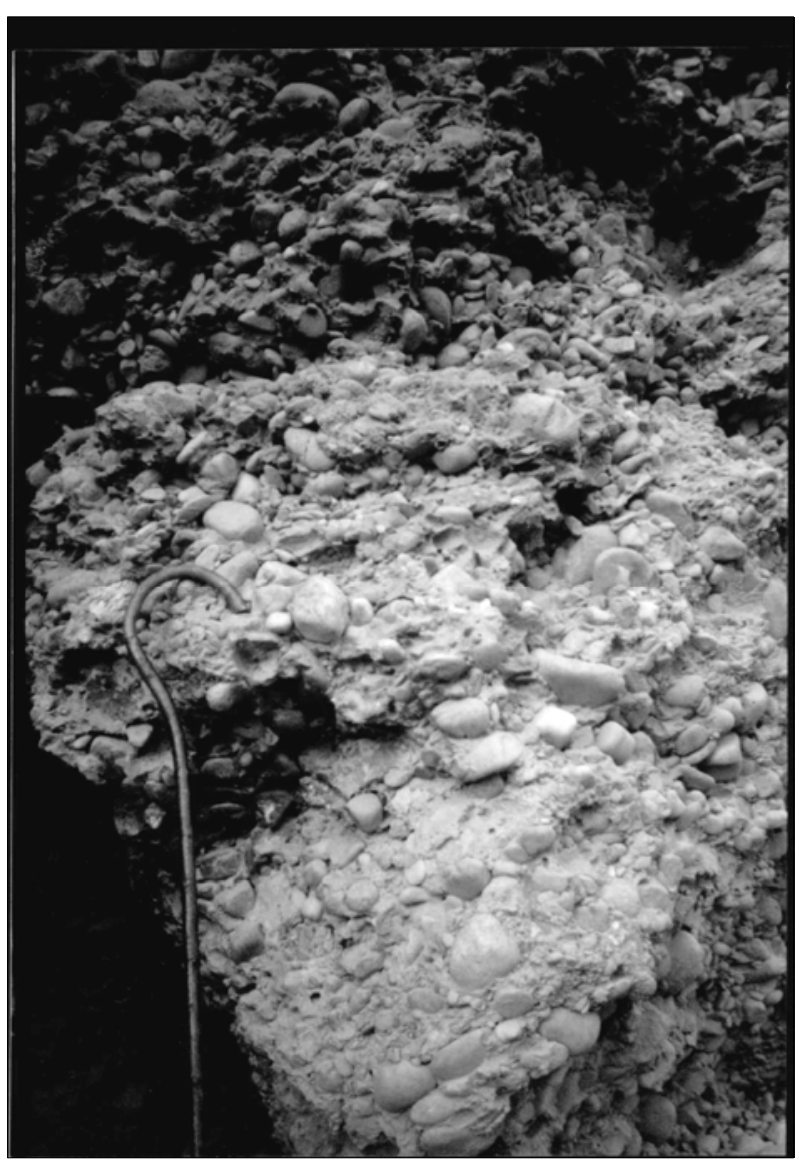

Plate 7: Massive and indurated conglomerate of Caves of plates (5 and 6).

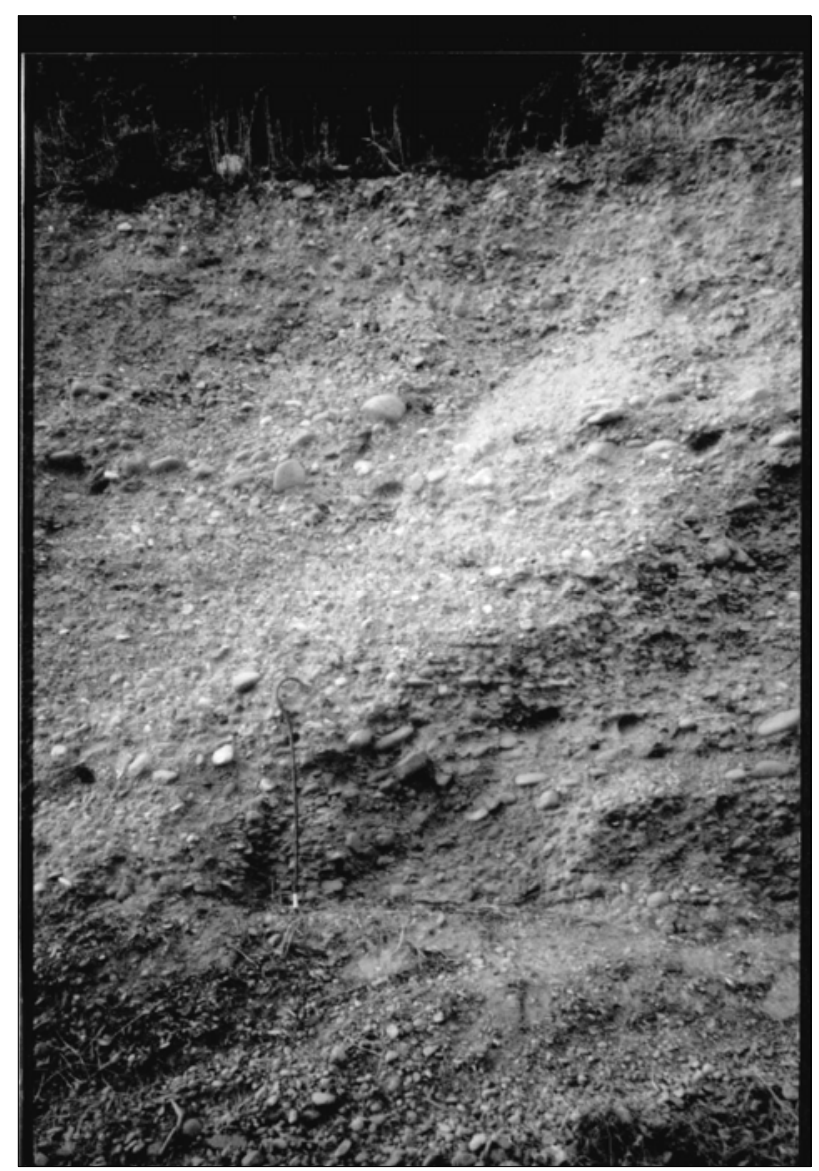

Plate 8: Fining upward sequence in the conglmerate of Caves of plates (5 and 6).

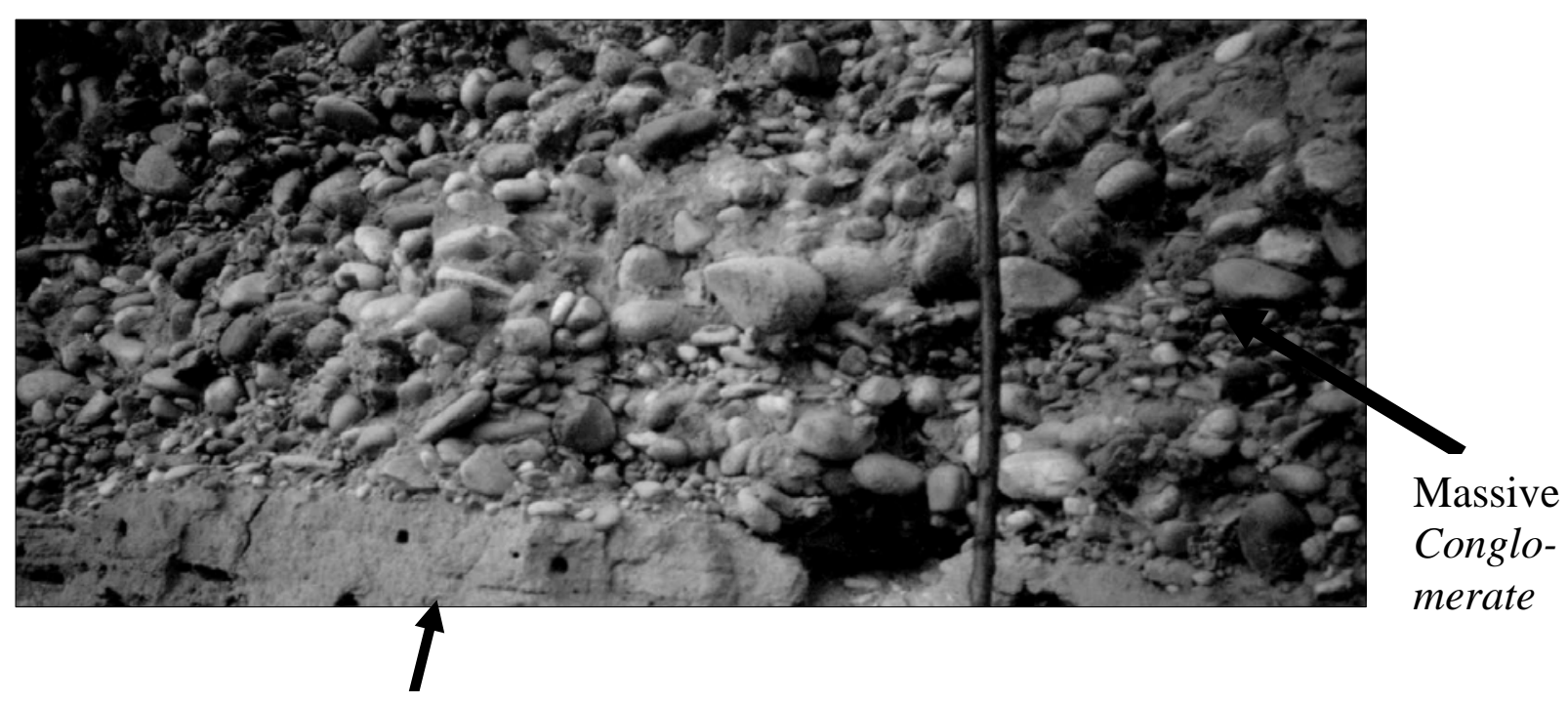

Lense of Sandstone

Plate 9: Lenses of sandstone in the conglomerate of Caves of plates (5 and 6). 
the lower water table where new system of passage ways begins to form. The abandoned channel way now forms an interconnected system of caves that could continue to enlarge as ground water percolating through them and dissolving the surrounding rocks. The area under present investigation is considered to be under semi-arid climate where the annual rainfall between (400-600) millimeter. Selby (1985) concluded that in arid and semi arid climate there is no possibility to initiate any karstic landforms because the water is not sufficient to dissolve the rocks. Al-Dewachi (2001), Al-Sabti et al. (1989) and Chapman. (1976) assigned the Pilstocene-Holocene times as possible times to initiate and developed karstification and also the caves in the conglomeritic unit.

\section{CONCLUSIONS}

The development and the formation of karstic phenomena as well as the caves in the conglomerate are considered to be a rare case even internationally . The only similar case to be compared with the area of study in Mosul is that of Italy.

Lithology is one of the main reason behined the formation of caves in Mosul ; the calcareous material that engulfed the pebbles and copples which form the conglomeritic rocks . The calcareous matrix is the most suitable material that to be dissolved by rainwater and undergroundwater.

Climate is the other main reason behind the caves formation , the present climate of Mosul region is semi - arid climate in which there is not enough water to dissolve the calcareous matrix .

Pliestocene-Holocene wet climate is the most likely time that the caves initiated and developed in conglomeritic deposits.

\section{REFERENCES}

Al-Dewachi, M. Bassam, 2001. A study of the initiation and the development of the valley network in general and blind and karstic valley especially at Jabal SheikIbrahim NW of Mosul. Iraqi Jour. Earth Sci., Vol.1, No.2, pp.11-22.

Al-Sabti, G.M., Jareshan, J.H. and Abdul-Karim, S., 1989. Gypsum karst in Sulavani area northwest Iraq. Iraqi Jour. Earth Sci., Vol.30, No.3, pp.357-369.

Belloni, S., Martins, B. and Orombelli, 1972. Karst of Itally in karst, important karst region of the northern hemisphere, Herak and Steringfield (editors), Elsevier Publishing Company, pp.85-128.

Blatt, H., Middlton, G. and Murray, R., 1972. Origin of sedimentary rocks, Prentice-Hall, Inc. Englewood cliffs, New Jersey, 634p.

Chapman, R.W., 1976. Calcareous Douricrust in Al-Hasa Saudi Arbia. Bull. Geol. Soc. of America, Vol.85, pp.1230-1248.

Geological Map of Mosul quadrangle, 1996, scale 1:250.000 printed and published in the state establishment of Geological Survey and Mining (GEOSURV), Baghdad, Iraq.

Jassim, S.Z., Jibril., A.S. and Numan, N.M., 1997. Gypsum karstification in Middle Miocene Fat`ha Formation, Mosul area, northern Iraq. Geomorphology, Vol.18, pp.137-149.

Monroe, S., James and Wicander Reed., 1992. Physical Geology, Exploring the Earth. West Publishing Company, 639p.

Montgomery, W., Carla., 1997. Fundamental of Geology, $3^{\text {rd }}$ ed., Brown, C. Wm. Publishers, 412p. 
Pettijohn, F.J., 1975. Sedimentary Rocks, $3^{\text {rd }}$ ed., Happer and Row, Publishers, 628p. Selby, M.J.,1985. Earths Changing Surface: An Introudction to Geomorphology. Caledonian Press-Oxford, 607p.

Thraikill John, 1968. Chemical and Hydrologic Factors in the Excavation of Limestone Caves. Bull. Geol. Soc. of America, Vol.79, pp.19-46. 